\title{
Isolated pyogenic tenosynovitis of tibialis anterior
}

\author{
Michael S Greenhalgh (1) , Karthikeyan P Iyengar, ${ }^{2}$ Chetan Sangani, ${ }^{2}$ Eugene M Toh ${ }^{2}$
}

${ }^{1}$ Department of Trauma and Orthopaedics, Lancashire Teaching Hospitals NHS Foundation Trust, Preston, UK ${ }^{2}$ Department of Trauma and Orthopaedics, Southport \& Ormskirk University Hospital NHS Trust, Southport, UK

\section{Correspondence to}

Michael S Greenhalgh: mikegreenhalgh@doctors.org.uk

Accepted 16 May 2020

\section{DESCRIPTION}

Pyogenic tenosynovitis is a bacterial infection of the synovial sheath that surrounds a tendon; commonly seen in the flexor tendons of the hand. Its aetiology is most commonly due to local penetrating trauma or haematogenous spread. Patients present with localised pain and swelling of the region. If the lower limb is affected, there may be an inability to weight bear. In the hand, Kanavel's signs may aid diagnosis. These are flexed posturing of the involved digit, tenderness to palpation over the tendon sheath, pain on passive extension and fusiform swelling of the digit. ${ }^{1}$ Staphylococcus and Streptococcus species are the most commonly isolated organisms associated with pyogenic tenosynovitis, though uncommon or atypical pathogens such as Mycobacterium tuberculosis have also been reported. ${ }^{2}$

Plain radiographs are typically non-specific. Complementary MRI may be helpful in establishing the anatomy and extent of infection. However, a high index of suspicion, good history and focused clinical examination are key factors in differentiating soft tissue pathology from adjacent joint infection.

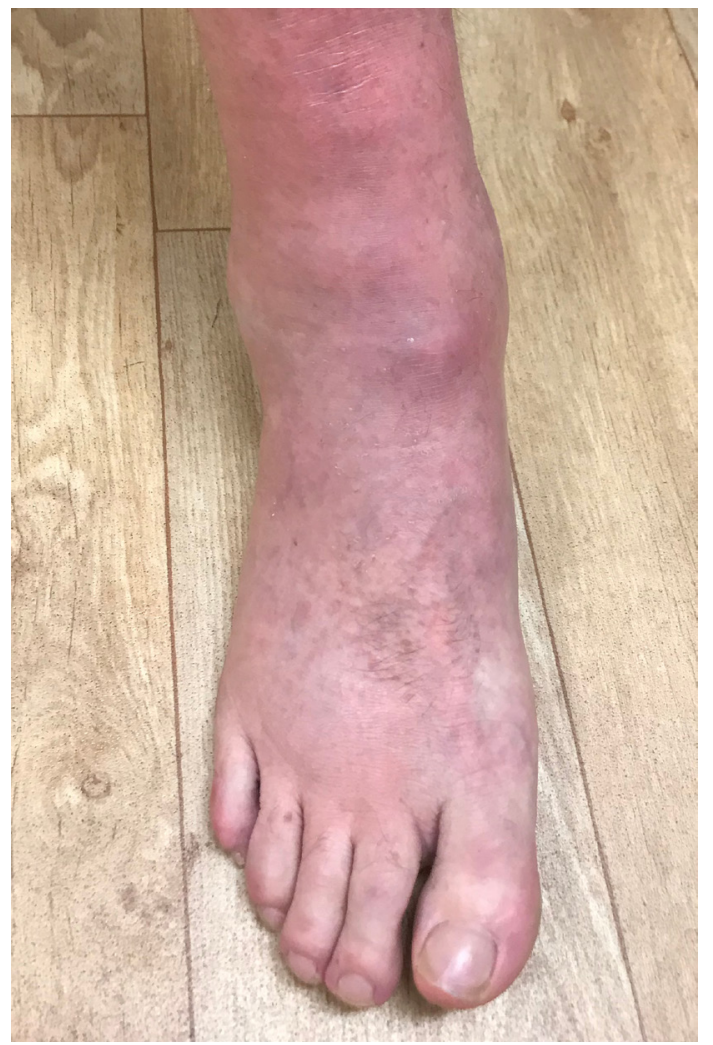

Figure 1 Clinical presentation with a diffuse medial swelling in the anterior compartment of the right leg.

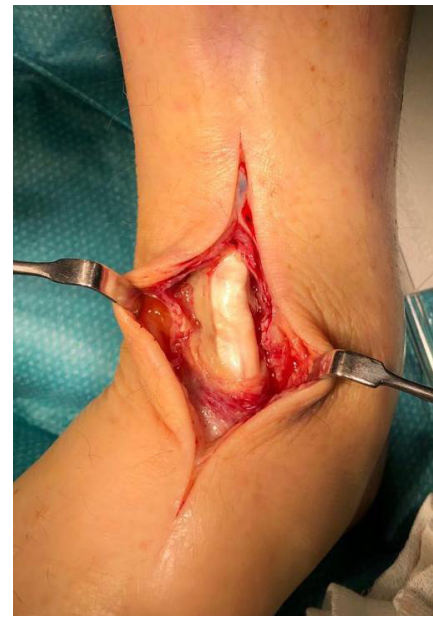

Figure 2 Intraoperative picture demonstrating thickening of tibialis anterior tendon, inflamed tenosynovium and pus within the tendon sheath.

Once pyogenic tenosynovitis is suspected, surgical debridement is required. ${ }^{3}$ It reduces infective load and intraoperative samples can identify the causative organism and its sensitivities to guide antibiotic therapy.

We present a rare case of primary infective tenosynovitis of tibialis anterior in a normally fit and well 50-year-old supermarket manager who presented to the emergency department with a week-long history of painful swelling to his right anterior leg and ankle. The swelling started as a $2 \mathrm{~mm}$ diameter lump overlying the anteromedial ankle, with no history of trauma or breaks to the skin of any kind. The patient had felt unwell for several days prior to presentation, describing nausea and rigours.

On examination, the patient was unable to bear any weight. There was a painful, diffuse swelling on the anteromedial aspect of the distal right leg and

\section{Learning points}

- Isolated pyogenic tenosynovitis of the leg compartments without a predisposing cause is extremely rare and a high index of suspicion is required.

- Plain radiographs may show soft tissue swelling, but frequently are non-specific. MRI may help in establishing the site, anatomy and extent of infection. Diagnosis can be made via a targeted clinical examination, similar to assessing Kanavel's signs in the hand.

- Surgical exploration helps in reducing infective load, microbiological diagnosis and definitive treatment. 
ankle. The pain was exacerbated by the stressing of the tibialis anterior, specifically with resisted active dorsiflexion of the right ankle. Passive movements of the right ankle were painless with no effusion (figure 1).

Plain radiographs were unremarkable. Inflammatory markers were raised, with C-reactive protein (CRP) of $128 \mathrm{mg} / \mathrm{L}$ and a neutrophil leucocytosis at $7.9 \times 10^{9} / \mathrm{L}(1.8-7.5)$. The total white cell count was within the normal range at $9.4 \times 10^{9} / \mathrm{L}$. Aspiration of the ankle joint resulted in a dry tap.

Based on clinical signs and symptoms, the patient underwent surgical drainage, debridement and washout of the tibialis anterior tendon sheath. Intraoperative findings revealed a thickened tendon with soft tissue oedema of the tendon sheath characteristic of an inflammatory process. There was frank pus contained within the sheath (figure 2).

Intraoperative microbiological samples identified Staphylococcus aureus as the causative organism. A 2-week course of intravenous flucloxacillin $2 \mathrm{~g}$ four times per day was administered, followed by a 4-week course of oral flucloxacillin $1 \mathrm{~g}$ four times per day on microbiology advice.

The inflammatory parameters improved over the treatment period, with the patient's CRP returning to normal. Outpatient clinical follow-up review revealed a well-healed operative wound, successful return of function and resolution of symptoms.

Contributors MSG assessed the patient on presentation, assisting surgeon in the described operation, wrote the first draft and edited the submitted manuscript. KPI undertook a literature review and edited the first draft of the manuscript. CS was the operating surgeon. EMT was the consultant responsible for the care of the patient and made the diagnosis based on clinical signs and symptoms.

Funding The authors have not declared a specific grant for this research from any funding agency in the public, commercial or not-for-profit sectors.

Competing interests None declared.

Patient consent for publication Obtained.

Provenance and peer review Not commissioned; externally peer reviewed.

\section{ORCID iD}

Michael S Greenhalgh http://orcid.org/0000-0002-9248-0739

\section{REFERENCES}

1 Kanavel $A B$. The symptoms, signs, and diagnosis of tenosynovitis and major fascialspace abscesses. In: Kanavel AB, ed. Infections of the hand. 6th edn. Philadelphia, PA: Lea \& Febiger, 1933: 364-95.

2 Genç B, Solak A, Mayda A, et al. Isolated tuberculous tenosynovitis of the anterior tibial and extensor digitorum longus tendons. J Clin Imaging Sci 2013;3:37.

3 Grundy JRB, O'Sullivan RM, Beischer AD. Operative management of distal tibialis anterior tendinopathy. Foot Ankle Int 2010;31:212-9.

Copyright 2020 BMJ Publishing Group. All rights reserved. For permission to reuse any of this content visit

https://www.bmj.com/company/products-services/rights-and-licensing/permissions/

BMJ Case Report Fellows may re-use this article for personal use and teaching without any further permission.

Become a Fellow of BMJ Case Reports today and you can:

- Submit as many cases as you like

- Enjoy fast sympathetic peer review and rapid publication of accepted articles

- Access all the published articles

- Re-use any of the published material for personal use and teaching without further permission

\section{Customer Service}

If you have any further queries about your subscription, please contact our customer services team on +44 (0) 2071111105 or via email at support@bmj.com.

Visit casereports.bmj.com for more articles like this and to become a Fellow 